\title{
Democracy \& Act 11 of 2008 (Chapter VII, Article 27, Paragraph 3)
}

\section{Yudha Fernando Silitonga}

Department of Information Technology, Swiss German University, Tangerang 15143, Indonesia

\section{Article Information}

Received: 8 December 2018

Accepted: 9 February 2019

Published: 25 April 2019

DOI: 10.33555/ejaict.v6i1.60

\section{Corresponding Author:}

Yudha Fernando Silitonga

Email: yudha.silitonga@student.sgu.ac.id

ISSN 2355-1771

\section{ABSTRACT}

In this study, researchers are interested to see the potential threat of Act 11 of 2008 (Chapter VII, Article 27, Paragraph 3) to the values of democracy. Act No.11 of 2008 turned out to save a potential threat to the values of democracy in Indonesia. It is related to Chapter VII, Article 27, Paragraph 3 regulating defamation / or defamation. Through the article, the government can impose penalties for civil society if insulting / or defamation in cyberspace. Researchers using the method of literature study in collecting research material. In the analysis, the researchers used a model of interactive method of Miles and Huberman analysis.

Keywords: Cyberlaw, Democracy, Intelligence Activity 


\section{Preliminary}

Act No.11 of 2008 turned out to save a potential threat to the values of democracy in Indonesia. It is related to Chapter VII, Article 27, Paragraph 3 regulating defamation / or defamation. Through the article, the government can impose penalties for civil society if insulting / or defamation in cyberspace. Some examples of cases related insult / or defamation in the cyber world is the insult case Jogjakarta by Florence Sihombing. He was engulfed in Yogya residents in social media. This is due to florence write status deemed insulting to the citizens of Yogyakarta. Florence write status rejected it because irritated lining up in the path of a line of cars at a gas station ${ }^{\mathrm{i}}$.

In the trial held in the District Court (PN) of the city of Yogyakarta, prosecutors filed in jail for six months with a trial period of 12 months. In the trial, the public prosecutor Rr Rahayu assess Florence guilty of violating article 27 paragraph 3 junto article 45, paragraph 1 Electronic Information and Transaction Law (ITE). Based on the facts and witness testimony revealed at the hearing, prosecutors filed charges for six months in prison with probation of 12 months, and a fine of Rp 10 million subsidiary three months in prison ${ }^{\mathrm{ii}}$.

From the government side, cases of humiliation / or defamation against the city of Yogyakarta a positive impact on its own. Particularly if examined from contra intelligence methods (Pengamanan). Because, with the City Contempt case Yogyakarta by, then the government may have the legal power to take security precautions against the existence of the rule. This is to anticipate similar events like in Egypt, where the government of President can be deposed because of the role of social media in the cyber world. Intelligence activities in the form of raising to the public through social media in order to topple the government of President Mursyd been able to overthrow the authoritarian regime. All elements of society can come together to take action thanks to the mass-raising is done in social media.

\section{Theoretical basis}

Some researchers legal basis can serve to deepen the analysis of this study are as follows. Related contents of UU ITE as a potential threat to democratic values, contained in Chapter VII, Article 27, Paragraph 3 reads: Any person intentionally and without right to distribute and / or transmitting and / or make the inaccessibility of Electronic Information and / or Electronic Documents which have a charge of insult and / or defamation ${ }^{\text {iii }}$.

Related functions and activities of the intelligence in the form of "Pengamanan" (Contra Intelligence), the author cites of Law No.17 of 2011, Chapter II, Part 3, Article 6, paragraph 3 reads: Pengamanan (Contra Intelligence) referred to in paragraph (1) shall consist of a series of activities carried out planned and directed to prevent and / or against the effort, work, intelligence activities, and / or Party fight against the interests and national security ${ }^{\mathrm{iv}}$.

Related functions and activities of the intelligence in the form of "Penggalangan" (Covert Action), the author cites of Law No.17 of 2011, Chapter II, Part 3, Article 6, paragraph 4 reads: Penggalangan referred to in paragraph (1) consists of a series of efforts, work, activities and actions carried out in a planned and targeted to affect Goal to benefit the interests and national security . 
Intelligence and knowledge, that is, specific knowledge, prior knowledge of the intelligence to know things are going to happen ahead of others in the form of intelligence products. Therefore, the product of government intelligence can anticipate every possible threat (to the brand better anticipation), the adoption of strategic measures (to improve strategic) planning national policies and better (for better planning). In terms of what is commonly known, an intelligence agency usually takes four scope of activities that are often also known as the elements of intelligence ${ }^{\mathrm{vi}}$.

The first element is the collection. This term refers to the notion of collecting information related to threats to national security. This collection can be done in several ways, ranging from technical intelligence, open to exploitation through espionage.

The second element is called by the processing (analysis). The importance of this element because the information obtained is highly fragmented and often even contradict each other. The nature of this type of information has become the reason why there is a need to carry out a treatment that is expected to result interpretation and evaluation appropriate and useful in decision making. The third element is known as a closed action (covert action). The scope of this intelligence is an activity that is highly confidential and controversial because it seeks to directly influence political events.

The fourth element is the counterintelligence activities. This activity intends to take measures in order that the enemy (opponents) are not getting the information they want. Protection may be disinformation designed to keep the enemy draw the wrong conclusions about the capabilities, intentions and actions owned by a country.

\section{Methodology}

This thesis uses a qualitative methodology with interpretive approach. The objective of this study is to investigate the authenticity of global response through certain stages to answer questions freely and measurable research. Qualitative research seeks to construct reality and understand its meaning. Therefore, qualitative research is usually very concerned about processes, events and authenticity ${ }^{\mathrm{vii}}$.

\subsection{Data Collecting Method}

The techniques used to obtain the data is through documentation study of books, magazines, internet and references. Data were obtained and then classified and qualified. This technique will certainly be the right tool to get the desired data to complete the analysis.

The data obtained will be divided into primary data and secondary data. The use of literature written by Hank Prunckun in the Manual scientific methods Research Intelligence Analysis contains the standardization and scientific methodology of the complete intelligence. The standard data collection refers to the recommendation Prunckun recommends several methods of collecting data on the investigation of intelligence ${ }^{\text {viii }}$.

\subsection{Analytical Method}

Step analysis of the data used in this study are interactive model of Miles and Huberman analysis. According to Miles and Huberman, phases of data analysis in this research that the 
researchers carried out the activities that occur in the field of recording objectively, then record the results are grouped or classified in detail according to the keywords listed. In addition, analysis Miles and Huberman performed interactively and lasted continuously until complete $^{\mathrm{ix}}$.

Activities in the data analysis consists of three steps.

- Data reduction is to summarize the activities, choose the subject matters, focusing on things that are important, and then look for themes and patterns. The activity was conducted based on data obtained from the field which is quite a lot.

- Data display : an activity presents data that has been reduced. The presentation of generating data that is organized and arranged in a pattern of relationships, so it's easier to understand.

- Conclution drawing : an activity conclusion. The conclusion is a new finding that a description or picture of the object under study.

\section{Case Study}

\subsection{Egypt Case}

In the case of Egypt, social media really help in the smooth demonstrations in Egypt. Because, on January 28, the competent authorities shut down internet and mobile phone services as well as deploy elite troops armed to the teeth, including tanks, anti-riot cars. The administration of President Hosni Mubarak will increasingly feel threatened by the brutal actions of the demonstrators ${ }^{\mathrm{x}}$.

Although many people recognize that a major demonstration oppose Mubarak in early 2011 and motivated by the success of large demonstrations that occurred in Tunisia, but the actual movement of opposition to Mubarak had started long before the Tunisian turmoil. Hate against Mubarak and his regime started sticking in 2000, when he ran back into the presidential referendum system. Over referendum undemocratic system that, mucullah movement "Kefaya" (Enough So President) led by human rights activists across political ideologies such as George Ishak.

It seems that the Egyptian people's patience has run out after the last parliamentary elections in November 2010 by Mubarak's party won absolute power. Leaving only 15 seats for the opposition, after the previous period the opposition gets more than 100 seats, including 80 for the Brotherhood activists. Allegedly the strong election laden with fraud and political engineering to pave Muabrak plan that will inherit this throne in September 2011. Meletuslah so bloody revolution of the Egyptian people on January 25, 2011 last.

The Egyptian Revolution originated from the initiative and awareness of one of the employees of one large company based internet that Google has a duty in the Middle East region, which incidentally is a resident of Egypt, the figure of the employee named Whael Ghonim who create Facebook account 'We are all Khaled Said' on July 2010. the account is then appeal to the masses very much, especially into government opposition.

The account is created Ghonim as a form of sympathy for Khaled Said who became victims of torture members of the Egyptian police in an Internet cafe in Alexandria, death unnatural with 
various injuries were horrific make everyone angry and did not receive for these actions. The account then becomes a medium of communication anti-government group in movement demonstration.

Once your account is 'We are all Khaled Said', supporters Ghanim then create another Facebook account, one account '6th of April Youth Movement' which is also used for antigovernment movement. In addition to Facebook, twitter is also used as a medium of communication, namely by using the hashtag \# jan25. Through twitter, protesters to communicate and provide information about the development of the demonstrations in Egypt.

Date January 25, 2011 Egyptian society began doing demonstrations and took to the streets demanding the resignation of President Hosni Mubarak. Thousands of people gathered at the Tahrir Square, Cairo. They were protesting over all evil Hosni Mubarak for power, especially on large-scale corruption and the silencing of a voice which he did.

The protests were carried out massive government opposed the Egyptian people. Date January 26, 2011 clashes between the Egyptian people and the police. Clashes occur because the demonstrators did not heed the ban on demonstrations issued by the government. The victims began to fall and many demonstrators were arrested. News of the clashes quickly spread on social media. Facebook and Twitter enlivened with blasphemy, prayer, and a spirit of anger and passion depicting the Egyptian people's revolution.

Activities exchange of information through social networks, Facebook and Twitter, carried widely by the people of Egypt in order to plan the overthrow of the authoritarian regime of Egyptian President Hosni Mubarak. This step taken by the Egyptian people related to the prolonged economic crisis, widespread corruption and authoritarian leadership of President Hosni Mubarak. Once awakened public opinion in Egypt, millions of the masses down any street and turned into the people power movement.

\subsection{Other Cases}

In addition to these cases, in Indonesia itself actually UU ITE already ensnared several korban.Oleh Therefore, we should be careful post the article on social networks, because it can lead police. For writing in cyberspace can be dangerous carelessly. If write insult or slander spread, could face jail. Therefore, the author can be prosecuted under Article 27 Paragraph 3 of the Law on Information and Electronic Transactions (ITE) with the threat of a maximum of 6 years in prison or a fine of Rp 1 billion. The following 6 Case humiliation in social networks led to police ${ }^{\mathrm{xi}}$ :

- Regent Pangkep Batara Shamsuddin Hamid: regent called the most stupid written across Indonesia as citizens in the social network Facebook. Syamsudin insult Budiman also complained to the police station. As a result of his comments on Facebook that, Budiman (37), a teacher of SMPN Ma'rang, Pangkep, South Sulawesi, have to deal with the Pangkep Police

- Farhat Abbas: Farhat Abbas' tweet who attacked Jakarta Vice Governor' ethnic, Basuki Tjahaja Purnama (Ahok), have lasting impacts. Anton who is the Chairman of Indonesian Chinese Muslim Association (PITI), reported Farhat Abbas to the police. 
Farhat Abbas attacked Ahok in his Twitter account. In @ farhatabbaslaw account, the lawyerwrites@farhatabbaslaw: here there Ahok personal vehicle number B 2 DKI sold by the Police to the public, He said! Ahok, simply because the number of vehicles made problems! Whatever the vehicle number, he is still $\mathrm{C} * * *$ !

- Denny Indrayana: Wamenkum Human Rights Denny Indrayana chirping in the network Twitter on August 18, 2012, 'Advocate corrupt is corrupt.' Denny gives a description that criminals who quipped when it is' advocates who defend blindly origin. Shamelessly receive payment of the proceeds of corruption. OC Kaligis report Denny to Polda Metro Jaya. In the police report numbered LP / 2010 / VIII / 2012 / PMJ / Dit.Reskrim.Um was dated August 23, Denny said to have defamation and insult related to his statements on social media mentions corrupt defense lawyers are corrupt.

- Yusril Ihza mahendra: Chairman of the Presidium of the Indonesian Police Watch (IPW), Neta S Pane reported Yusril Ihza Mahendara to Polda Metro Jaya, Wednesday, May 18, 2011. Due to his twitter account, Yusril accused IPW is a group that only pretended idealistic but the ends, looking for a payday.

- Bondan Prakoso: Intention to express their feelings on social networking sites, Bondan Prakoso even have to deal with the police. He was reportedly on charges of defamation by Akasaka Cafe in Denpasar, Bali.

- Prof. Said Ruhpina: Teachers' Training College Rector Mataram reported lecturer of English Language and Literature Faculty of Education Institute of Teacher Training and Education Mataram, then Masum to the police. Then who disguise his identity on Facebook become Chunk Jagger often write insults to Said. According to the Head of Public Relations Mataram Police, AKP Arief Yuswanto, chances Party will be subject to Law Number 11 Year 2008 on Information and Electronic Transactions (UU ITE).

\section{Conclusions \& Suggestions}

From these facts, it can be concluded that there is potential for abuse of the ITE Law to silence democratic values in Indonesia. Party most benefit from these regulations is the government itself, not Rakyat Indonesia.

The advice can be given in order to anticipate misuse author UU ITE, is to set clear parameters and elaboration of the definition of the Act No. 11 of 2008 (ITE), Chapter VII, Article 27, Paragraph 3, which reads: Any person intentionally and without right to distribute and / or transmitting and / or make the inaccessibility of Electronic Information and / or Electronic Documents which have a charge of abusive and / or defamation.

With the elaboration of a clear and balanced parameters of the phrase "insult / or defamation", then UU ITE government cannot be used as a tool to silence democratic values in Indonesia. 


\section{References}

Kompas.com

Kompas.com

Act 11 of 2008

Act 17 of 2011

Act 17 of 2011

Ahmadharakan.com

Merdeka.com

Prunckun, H. (2010). Manual scientific methods Research Intelligence Analysis.

Somantri, G. (2005). Makara-Sosial Humaniora, 9. Memahami Metode Kualitatif .

Sugiyono (2008)

Widjajanto, A., C. L. (2006). Intelijen: Velox et Exactus. Pacivis \& Kemitraan. 